\title{
APPLICATION OF LIVE FEEDS IN THE FRESHWATER ORNAMENTAL FISH LARVAE OF PUNTIUS DORSALIS (JERDON)
}

B. Victor, M. Mannar Mannan, M. Maridass, P. Murphy Alexander and J.M.A.P. Arachi*

\section{ABSTRACT}

Feeding experiment conducted under laboratory conditions, to determine the suitability of live feed for the lanve of ornamental fish Puntius dorsalis, shows the increase of specific growth rate and weight gain when they were fed with mosquito lavae (3.284 and $8.04 \%$ ) day), chironomus larvae (3.308 and 6.24\%/day), chopped earthworm (2.659 and $4.391 \% /$ day) and plankton (2.618 and $4.39 \% /$ day). The maximum growth rate, $0.674 \mathrm{~g}$ was observed in mosquito lanae feed followed by chironomus larvoe $(0.522 \mathrm{~g})$, chopped earthworm $(0.41 \mathrm{lg})$ and plankton $(0.405 \mathrm{~g})$ feed. The present study indicates that mosquito larvae could be used as a suitable live feed for feeding Puntius dorsalis larval fishes.

Key words: Puntius dorsalis, Live feed, Plankton, Chopped earthworm, Mosquito larvae, Chironomus larvae

*. Animal Health Research Unit; St. Xavier's College, Poloyamkottai - 627002.

E-mail: repro_mannan@yahoo.co.in 


\section{Introduction}

Ornamental fishes have gained considerable attention in recent years. The Puntius (Cyprinidae) species are of fresh water fishes native to Southeast Asia. Their large scales, bright colors, schooling behaviour and ease of maintenance and breeding have made them popular in the aquarium trade (Clyde S. Tamaru ef al., 2001). Freshwater tropic fishes found in Indian waters are known for their vivid colours, their beauty and ability to live in confinement and to consume different varieties of food and peaceful nature. It is evaluated that out of 186 fish species, $62(33.3 \%)$ are considered as only food fish followed by $53(28.4 \%)$ as only ornamental. Farming freshwater tropical fish is a very competitive aquaculture venture. The initial stages of $P$. dorsalis is having eye catching feature of silvery white in colour. The black spots are present in front of the caudalfin on both sides. The adult fishes are hoving high commercial value. It is commonly called "Long snouted barb". The smalt scale farmers have successfully substituted low cost live feeds such as planktons, water fleas, tubicid worms, mosquito larvae and chopped earthworm. In ornamental fish farming, live food organisms, especially Artemia and rotifers, are extensively used as the main food sources for the larviculture. Both the food organisms are filter feeders and have successfully been applied as biological carriers for transferring essential nutrients to predator larvae (Leger et al., 1986).

The blood worms (chironomus) are ideal live food source to all varieties of ornamental fishes (Jameson and Santhanam, 1996). Samantaray and Mohanty (1997) have formulated pelleted feeds (instead of live feed) to the larvae resulting in poor survival. Since the digestion in post-larvae takes place because of enzymes absorbed from live prey. In the study, we have selected four types of live feeds like, plankton, chopped earthworm, mosquito larvae and chironomus larvae for the assessment of growth and survival.

\section{Materials and Methods}

P. dorsalis larvae, weighing 140-170 $\mathrm{mg}$ were collected from Tamprabarani river, Tirunelveli, Tamil Nadu. They were maintained at $29^{\circ} \mathrm{C}$ in cement cisterns and fed with planktons, till the start of the experiment. Feeding trials were carried out for a culture period of 35 days in $50 \mathrm{~L}$ plastic troughs. Each trough was stocked with 50 larvae, and it was maintained with water temperature of $29 \pm 0.5^{\circ} \mathrm{C}$, dissolved oxygen 6 to $6.8 \mathrm{mg} / \mathrm{l}$ and $\mathrm{pH}: 6.8$ to 7.4 throughout the experiment. Larvae were fed on plankton, chopped earthworm, mosquito larvae and chironomus larvae separately thrice a day $(8 \mathrm{hr}, 13 \mathrm{hr}, 18 \mathrm{hr}$ ) ad libitum. The water was changed every day. The live feeds were treated with 20 ppm formalin for $10-15 \mathrm{~min}$ and washed 
thoroughly with tap water prior to feeding to avoid introduction of pathogens and parasites which are normally associated with live natural food (Uys and Hecht, 1985).

At the end of the experiment, each fish was weighed and its body length was measured. The specific growth rate (SGR) and weight gain (\%) were estimated with the help of following formulas.

\section{Mean growth rate (\%/day)}

$$
=\frac{\text { Final mean weight }- \text { Initial mean weight }}{\text { Initial mean weight } / \text { No. of days }} \times 100
$$

\section{Specific growth rate (\%/day)}

$$
=\frac{\log ^{e} \text { final mean weight }- \text { Loge initial mean weight }_{\text {No. of days }}}{\text { Not }}
$$

\section{Weight gain (\%/day)}

$$
=\frac{\text { Mean final fish weight }- \text { Mean initial fish weight }}{\text { Mean initial fish weight }} \times 100
$$

\section{Survival rate (\%)}

$$
=\frac{\text { Final total number of fish live }}{\text { Initial total number of fish }} \times 100
$$

\section{Result and Discussion}

In present study of 35 day experiment, the larvae consumed the live feed well and the acceptability of all the feeds was similar. Data for mean growth rate, specific growth rate and weight gain are presented in Table 1 and they have also been graphically represented in Figs. 1 -5. The highest growth rate (36.5 mm length) of 
$8.04 \% /$ day and weight $(0.614 \mathrm{~g})$ was observed in $P$. dorsalis larvae fed with mosquito larvae, followed by 6.24 and 4.39 and $4.29 \%$ /day those fed on chironomus larvae (33.27 $\mathrm{mm}$ length and $0.522 \mathrm{~g}$ weight), chopped earthworm $(31.4 \mathrm{~mm}$ length and $0.411 \mathrm{~g}$ weight) and planktons ( $30.92 \mathrm{~mm}$ length and $0.405 \mathrm{~g}$ weight). The highest specific growth rate of $3.82 \%$ /day was observed in larvae fed on mosquito larvae, whereas the $3.31,2.66$ and $2.61 \% /$ day was noticed in those fed on chironomus larvae, chopped earthworm and planktons. The highest weight gain $(8.04 \% /$ day) and survival rate $(90 \%)$ were observed in P. dorsalis, fed on mosquito larvae whereas the lowest weight gain (4.29\%/day) and survival rate $(86 \%)$ were observed in those fed on planktons. The similar findings were observed in Puntius vittatus fed on mosquito larvae (Jasmine, 2004). Marimuthu et al. (19.99) reported that the larvae of Channa striatus fed on mosquito larvae have the highest growth rate, specific growth rate and weight gain than chironomus larvae and planktons. Dabrowski (1982) suggest that initially, enzymes present in the live prey enhance the digestion in the fish larvae.

Table 1: Growth responses of Puntius dorsalis fed on different live feeds.

\begin{tabular}{l|c|c|c|c}
\hline \multirow{2}{*}{ Parameters } & \multicolumn{4}{|c|}{ Feed types } \\
\cline { 2 - 5 } & Planktons & $\begin{array}{c}\text { Chopped } \\
\text { earthworm }\end{array}$ & $\begin{array}{c}\text { Mosquito } \\
\text { larvo }\end{array}$ & $\begin{array}{c}\text { Chironomus } \\
\text { lava }\end{array}$ \\
\hline Initiol mean length $(\mathrm{mm})$ & $17.2 \pm 0.81$ & $17.2 \pm 0.74$ & $17 \pm 0.66$ & $17.3 \pm 0.89$ \\
Initial mean weight $(\mathrm{g})$ & $0.162 \pm 0.02$ & $0.162 \pm 0.012$ & $0.161 \pm 0.016$ & $0.164 \pm 0.011$ \\
Final mean length (mm) & $30.92 \pm 0.036$ & $31.4 \pm 1.2$ & $36.5 \pm 1.4$ & $33.27 \pm 0.96$ \\
Final mean weight $(\mathrm{g})$ & $0.405 \pm 0.036$ & $0.411 \pm 0.024$ & $0.614 \pm 0.24$ & $0.522 \pm 0.21$ \\
Mean growth rate $(\% /$ day) & 4.285 & 4.391 & 8.039 & 6.237 \\
Specitic growth rate $(\% /$ day) & 2.618 & 2.659 & 3.824 & 3.308 \\
Weight gain (\%/day) & 4.29 & 4.39 & 8.04 & 6.24 \\
Sunvival & 86 & 88 & 90 & 88 \\
\hline
\end{tabular}

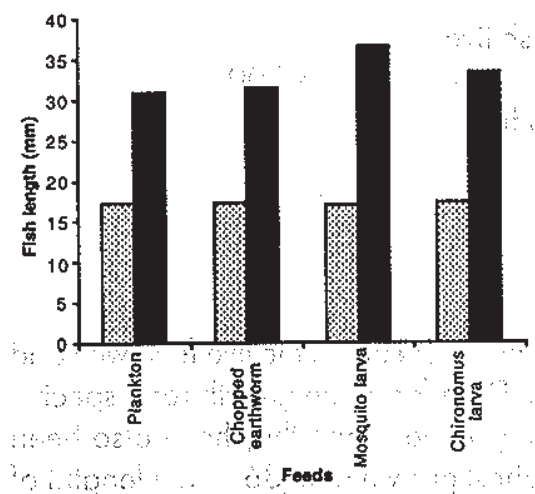

BInitial length

@ Final length

Fig. 1: Growth length (\%/day) by $P$. dorsalis fed on different live feeds after 35 days. 


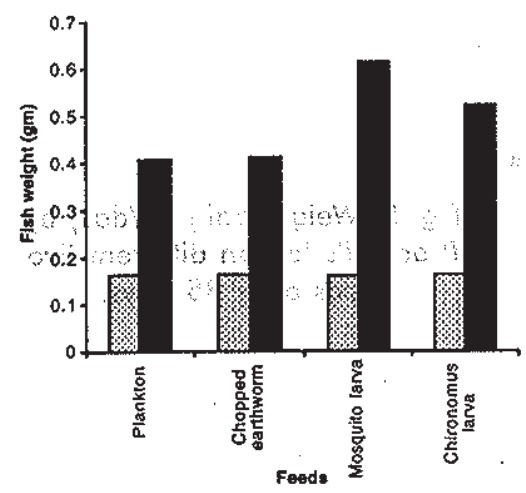

Dinitial weight

a:Final weight

Fig. 2: Growth weight (\%/day) by P. dorsalis fed on different live feeds after 35 days.

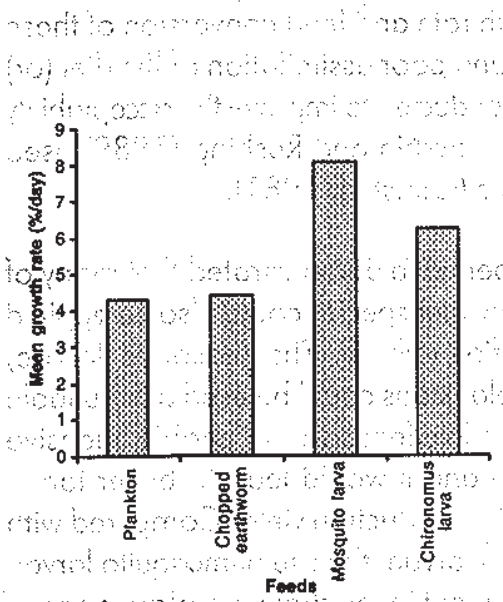

Mean growth rate

Fig. 3. Mean growth rate (\%/day) by $P$ dorsalis fed on different live feeds after 35 days.

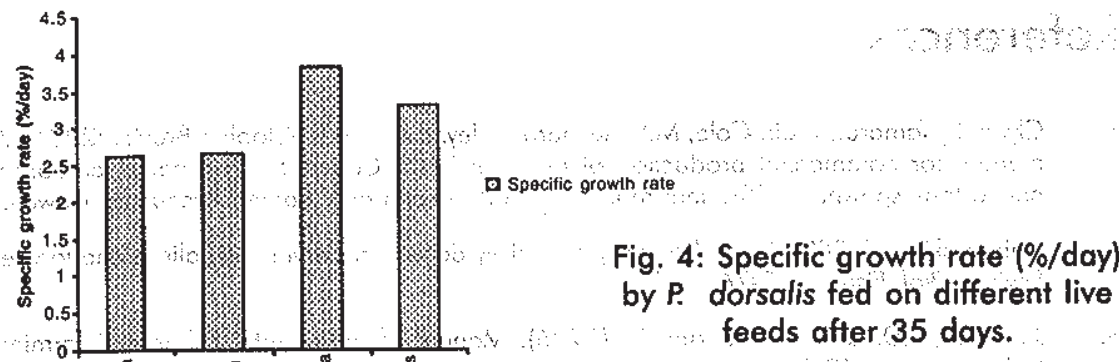




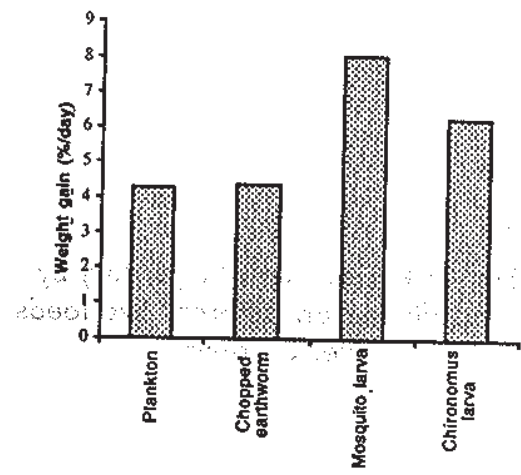

v Woight gain

Fig. 5, Weight gain (\%/day) by P. dorsalis fed on different live feods after 35 days.

Wilson ef al. (1981) reported that poor growth rate and feed conversion of these fish could be attributed to the poor digestion and poor assimilation of the diet (or) its unattractiveness. Several studies have been conducted to improve the acceptability and feed consumption of experimental diets. Lovshin and Rushing (1989) used feed attractants for catfish, Ameiurus nebulosus (Olmsted, 1981).

The experimental results presented in this paper have demonstrated that many of the live feeds used for larval production of freshwater species could also be applied successfully in the fresh water ornamental fish culture. The mosquito larvae, chironomus larvae, chopped earthworm and planktons could be used as a suitable live feed for feeding early larvae. Use of these live feeds would enable intensive larviculture of the freshwater ornamental fish and it would lead to better larval performance and an exponential increase in the production yield. Compared with plankton, chopped earthworm and chironomus larvae, the use of mosquito larvae for feeding would result in significant improvement in the growth performance of the larvae of $P$. dorsalis and better survival rate.

\section{References}

1. Clyde, S. Tamaru., Brain Cole, M.S., Richord Bailey, B.A. and Chistopher Brown. (2001). A manual for commercial production of the tiger barb, Capoeta tetrazona, a temporary paired tank spawner. CTSA final report. Depart, of Land and Natural Resources, Hawaii.

2. Dabrowski, K. (1982). Proteolytic enzyme activity decline in starving fish aliens and larvae.

3. Jameson, J.D. and Santhanam, R. (1996). Manual of ornamental fishes and farming technologies. 6:60-72.

4. Jasmine, S.N. (2004). Nutritional evaluation of chosen pellet and live feeds on growth haemogram and reproduction of the ornamental fish, Puntius vittatus - M.Phil thesis Manonmaniam Sundaranar University, Tirunelveli. 
5. Leger, P., Bengtson, D.A., Simpson, K.L." and Sorgeloos, P. (1986). The use and nutritional value of Artemia as a food source. Oceanogr. Mar. Biol. Ann. Rev., 24:52 1-623.

6. Lovshin, L.L. and Rushing, J.H. (1989). Acceptance by large mouth bass fingerlings of pelleted feed with a gustatory additive. The progressive fish culturist. 51:73-78.

7. Marimuthu, K., Muruganandam, M. and Hanifa, M.A. (1999). Rearing of larvae is an essential pre-requisite for murrel culture. Fishing Chimes. 18(12):31-32.

8. Olmsted, J.M.D. (1918). Experiments on the natural of the sense of smell in the common cattish, Ameiurus nebulosus. Am. J. Physiol., 46: 443-458.

9. Samantaray, K. and Mohanty, S.S. (1997). Interactions of dietary levels of protein and energy on fingerlings snakehead, Chonna striafus. Aquaculfure 156:241:249.

10. Uys, W. and Hecht, T. (1985). Evaluation and preparation of optimal dry feed for primary nurshing of Clarias gariephinus larvae (Pisces: Claridae). Aquaculture 47:173-183.

11. Wilson, R.P., Robinson, E.H. and Poe, W.E. (1981). Apparent true availability of amino acids from common feed ingredients for channel catfish J. Nutr, 111:923-929. 